\title{
THE EFFECTS OF OCEAN ACIDIFICATION ON WOUND REPAIR IN THE CORAL PORITES SPP.
}

Peter J Edmunds ${ }^{\dagger}$, Alex Yarid

Running head: Ocean acidification and damage in corals

Key words: Scleractinia; healing; climate change; Moorea; coral reef

Department of Biology, California State University, 18111 Nordhoff Street, Northridge, CA 91330-8303, USA 


\begin{abstract}
Scleractinian corals on tropical reefs are exposed to many natural and anthropogenic disturbances, and while much is known about their responses to such conditions, it is unclear whether the responses will remain the same in a future affected by climate change and ocean acidification. To evaluate how one aspect of these effects -- wound repair -- might be influenced by ocean acidification, small colonies of massive Porites spp. from the back reef of Moorea, French Polynesia, were damaged to simulate the effects of single bites by corallivorous fishes, and healing was measured under contrasting $P_{\mathrm{CO} 2}$ regimes. Using experiments lasting 19-20 d and employing superficial (2013) or deep (2014) lesions, the effects of damage were evaluated at $\sim 400 \mu \mathrm{atm}$ (ambient) and $\sim 1,000 \mu \mathrm{atm} P_{\mathrm{CO} 2}$ (both at $\sim 28.5^{\circ} \mathrm{C}$ ) using calcification and healing as dependent variables. Damage reduced calcification of massive Porites spp. in 2013, but not in 2014, and $P_{\mathrm{CO} 2}$ had no effect on area-normalized calcification or healing in both years, although biomass-normalized calcification was reduced by high $P_{\mathrm{CO} 2}$ in 2014 . Overall these results reveal the physiological resilience of this functional group of corals to the extent of ocean acidification expected by the end of this century, and suggest that over this period small colonies will remain capable of recovery from minor damage arising from fish corallivory.
\end{abstract}




\section{Introduction}

In the marine environment, the ability of colonial modular organisms to recover from partial mortality mitigates the negative effects of damage (Jackson and Coates, 1986). This is important for sessile taxa that cannot flee from sources of damage, and for those that are iteroparous, successful repair can increase the likelihood of future reproduction (Henry and Hart, 2005). The ability to survive damage is made possible by the capacity to regenerate damaged tissue, or to survive the loss of tissue if repair is impossible (Henry and Hart, 2005). There is a long history of interest in the regenerative capacity of colonial modular organisms (Jackson, 1979; Palumbi and Jackson, 1982; Hughes, 1983), and tropical scleractinians have served as a model system in advancing this interest (e.g., Nagelkerken and Bak, 1998; Oren et al., 2001).

Scleractinians frequently experience partial mortality through corallivory and breakage (Reese, 1977; Frydl, 1979; Rotjan and Lewis, 2008; Bruckner and Bruckner, 2016), and these events typically create lesions in which tissue and skeleton are removed (Henry and Hart, 2005). The combined effects of these lesions can sum among members of a population to represent greater tissue loss than occurs through the death of whole colonies (Hughes and Jackson, 1985). Lesions attributed to corallivory are a chronic disturbance for those scleractinians targeted by fish corallivores (Rotjan and Lewis, 2005), but the extent of damage inflicted varies among species of fish (Bellwood and Choat, 1990; Rotjan and Lewis, 2008). Some fish remove individual polyps without damaging the skeleton, while others remove large amounts of skeleton and tissue (Cole et al., 2008). For many years there was scant evidence that fish corallivory had strong effects on scleractinian communities (Hixon, 1997; Coles et al., 2008; Rotjan and Lewis, 2008), but this 
disturbance is now viewed as an important factor affecting the abundance, distribution, and fitness of scleractinians (Cole et al., 2008; Rotjan and Lewis, 2008).

When a scleractinian is damaged, repair requires the allocation of resources to replace damaged tissue, and subsequently biological functions, including growth and reproduction, may be impaired as resources are prioritized for this purpose (Rinkevich, 1996; Henry and Hart, 2005). The rate at which tissue is regenerated is important, because the likelihood that fouling organisms will colonize lesions increases with the duration of exposure of skeleton within the lesion (Meesters et al., 1997; Henry and Hart, 2005). Once fouling organisms colonize a lesion, it is unlikely that coral tissue will grow over the site of damage (Meesters et al., 1997). Whether coral tissues regenerate is determined by intrinsic factors, such as corallum morphology, the supply of interstitial cells, and the availability of metabolic energy (Meesters et al., 1996; Henry and Hart, 2005), as well as extrinsic factors including seawater depth and the magnitude of damage (Meesters et al., 1997; Nagelkerken et al., 1999). As global climate change leads to increases in seawater temperature (Bindoff et al. 2007), and reduced seawater $\mathrm{pH}$ (i.e., ocean acidification [Doney et al., 2009]), determining how extrinsic factors influence tissue repair in scleractinians will help to understand how they will respond to damage in the future.

Most research on the effects of ocean acidification on scleractinians has focused on calcification (Erez et al., 2011), but this phenomenon has the potential to affect other biological functions (Doney et al., 2009). As studies of the response of scleractinians to ocean acidification have broadened their consideration of treatment conditions, there has been growing attention to interactive effects, such as might occur in synergy with elevated temperature, feeding, light 
intensities, and flow speeds (Erez et al., 2011; Chan and Connolly, 2013; Edmunds et al., 2012;

Comeau et al., 2014a). To date, the possibility that ocean acidification could modulate recovery from partial mortality has rarely been considered (but see Renegar et al., 2008; Horwitz and Fine, 2014; Hall et al., 2015). Since changes in environmental conditions associated with ocean acidification could influence the availability of cellular and energetic resources for tissue regeneration, it is reasonable to hypothesize that tissue regeneration will be affected (Henry and Hart, 2005).

This study investigated the effects of ocean acidification on the recovery of a scleractinian from partial mortality. Two experiments were performed to address the effects of modest (in 2013) and severe (in 2014) damage on the common Indo-Pacific coral, massive Porites spp. Experiment 1 tested the effects of ocean acidification on calcification and tissue regeneration in corals recovering from damage created with a scar extending $2-3 \mathrm{~mm}$ into the skeleton and tissue. Experiment 2 was similar, except that damage was more severe and consisted of a scar removing tissue and skeleton extending 5-6 $\mathrm{mm}$ into the skeleton and tissue. Both experiments were conducted with small colonies of massive Porites spp. from the back reef in Moorea, French Polynesia, and colonies were incubated in mesocosms supplied with flowing seawater, and controlled for $P_{\mathrm{CO} 2}$, temperature, and irradiance. Corals were damaged to simulate corallivory resulting from fishes feeding in scraping (Experiment 1) and excavation (Experiment 2) feeding guilds (Bellwood and Choat, 1990). 


\section{Materials and Methods}

\section{Collection and acclimation}

Experiments took place at the Richard B. Gump South Pacific Research Station on Moorea, and used small colonies ( $4 \mathrm{~cm}$ diameter) of massive Porites spp. from 2-3 m depth in the back reef. Massive Porites spp. was used because small colonies of this taxon are common throughout the back reef, where they are subject to corallivory (Lenihan and Edmunds, 2010). Moreover, throughout the Indo-Pacific, members of this group play important roles in coral reef community structure. In Moorea, the back reef is populated by at least three species of massive Porites spp., with $P$. lutea and P. lobata particularly common (Bosserelle et al., 2014). These species are distinguished by corallite structure (Veron and Pichon, 1982), but the differences are difficult to detect underwater, and may not conform to species boundaries discerned from genetic tools (Forsman et al., 2009). Therefore, small colonies of similar shape, color, and size were combined as massive Porites spp., which previously we have distinguished using morphological features to $85 \%$ P. lutea and $15 \%$ P. lobata (Edmunds, 2009).

An experiment was designed in which corals were damaged in a standardized way (i.e., scars of similar area and depth), and grown in mesocosms under two $P_{\mathrm{CO} 2}$ levels. Each $P_{\mathrm{CO} 2}$ treatment was created in replicate tanks containing multiple corals to alleviate the limitations of pseudeoreplication (sensu Hurlbert, 1984) (described below). In Experiment 1, six corals were allocated to each treatment combination (damage versus undamaged $\times P_{\mathrm{CO} 2}$ ) in each of three tanks at both $P_{\mathrm{CO} 2}$ treatments ( 72 corals), and in Experiment 2, 10 corals were allocated to each treatment combination in each of two tanks at both $P_{\mathrm{CO} 2}$ treatments ( 80 corals). 
Corals were brought to the laboratory and attached to plastic tiles using epoxy (Z-Spar A-788, Splash Zone Compound Los Angeles, CA, USA) without damaging marginal tissues to induce a stress response. To allow recovery following collection, corals were retained in a $1000 \mathrm{~L}$ tank for $7 \mathrm{~d}$ in Experiment 1 (at $28.8^{\circ} \mathrm{C}$ and $481 \mu$ mol quanta $\mathrm{m}^{-2} \mathrm{~s}^{-1}$ irradiance) and $6 \mathrm{~d}$ in Experiment 2 (at $28.9^{\circ} \mathrm{C}$ and $489 \mu \mathrm{mol}$ quanta $\mathrm{m}^{-2} \mathrm{~s}^{-1}$ irradiance). Temperature was measured with a certified digital thermometer $\left( \pm 0.05^{\circ} \mathrm{C}\right.$ model $15-077$, Thermo Fisher Scientific, Waltham, MA, USA), and light intensity with a 4- $\pi$ quantum light sensor (LI-193SA sensor and LI-1400 meter, LICOR, Inc., Lincoln, NE, USA), and the levels of these factors were similar to the conditions at the site of collection in April when the experiments were conducted. Light was provided using four LED lamps (LED System Model: Sol Blue, Aqualllumination® ${ }^{\circledR}$, Ames, IA, USA).

\section{Experimental treatments}

In both experiments, half of the corals were damaged using snub-nose pliers to scrape a rectangular lesion on their upper surface, and care was taken to ensure the lesions were similar in size. Pliers were rinsed in clean seawater between damaging colonies to avoid crosscontaminating replicate corals with mucus and microbes. In Experiment 1, which involved superficial damage, lesions had a mean area of $0.99 \mathrm{~cm}^{2}$ and penetrated $\sim 1-2 \mathrm{~mm}$ into the colony surface. In massive Porites spp., the coral tissue forms a layer 5-6 mm thick, and therefore this damage did not extend across the full width of the tissue. In Experiment 2, which involved deeper scars and more severe damage, lesions again were created with snub-nose pliers, but their area was increased to $2.5 \mathrm{~cm}^{2}$ and they were scraped to a depth of $\sim 5-6 \mathrm{~mm}$ into the skeleton. The dimensions of lesions were similar to those created by parrotfish feeding on 
massive corals (Bellwood and Choat, 1990; Rotjan and Lewis, 2005), with those created in Experiment 1 resembling bites of fishes in the scraping guild, and those in Experiment 2 resembling bites of fishes in the excavating guild (Bellwood and Choat, 1990). The other half of the corals was left undamaged and served as control for the damaged treatment.

Following damage, corals were retained in the acclimation tank for 1 day until mucus release attributed to damage ceased, and then control and damaged corals were randomly assigned to 150 L tanks (AquaLogic, San Diego, CA, USA) that were pre-set to treatment conditions (ambient and elevated $P_{\mathrm{CO} 2}$ ). Six tanks were used in Experiment 1 and four in Experiment 2, and all were supplied with fresh seawater at 100-200 $\mathrm{mL} \mathrm{min}^{-1}$. Half of the tanks were bubbled with ambient air, and the other half with $\mathrm{CO}_{2}$-enriched air to maintain $P_{\mathrm{CO} 2}$ at target values of $\sim 400$ $\mu$ atm (ambient) and $\sim 1,000 \mu$ atm (elevated). The elevated $P_{\mathrm{CO} 2}$ treatment corresponds to the pessimistic representative concentration pathway (RCP 8.5) that projects atmospheric $P_{\mathrm{CO} 2}$ to increase to $\sim 1,370 \mathrm{ppm}$ by 2100 (van Vuuren et al., 2011). Tanks were maintained at $28.0^{\circ} \mathrm{C}$ in Experiment 1 , and $28.8^{\circ} \mathrm{C}$ in Experiment 2, with the slight difference reflecting logistical constraints. Corals were incubated for $19 \mathrm{~d}$ in Experiment 1 and $20 \mathrm{~d}$ in Experiment 2, and were randomly repositioned within the tanks daily to account for position effects.

Tanks were monitored for temperature, irradiance, salinity, $\mathrm{pH}$, and carbonate chemistry. Temperature was measured twice daily using a digital thermometer and irradiance was measured using a 4- $\pi$ quantum PAR sensor and meter (both described above). In Experiment 1, irradiance in the tanks was measured weekly, and in Experiment 2 it was measured daily. 
In Experiment 1, salinity was recorded every $2 \mathrm{~d}$ using a conductivity meter (YSI 3100), and pH was measured 3 times $\mathrm{d}^{-1}$ (using a DG115-SC probe (Mettler-Toledo, Columbus OH, USA], fitted to an Orion 3 star meter [Thermo Fisher Scientific, Waltham, MA, USA], calibrated on the total scale using TRIS/HCl buffers [Dickson et al., 2007]). Total alkalinity (TA) was measured by potentiometric titration (T50, Mettler-Toledo) following SOP $3 b$ (Dickson et al., 2007), and initially was calculated daily and, once stable, every $2 \mathrm{~d}$. Carbonate chemistry parameters and $P_{\mathrm{CO} 2}$ were calculated using the SeaCarb package (Lavigne and Gattuso, 2012) in R software (R foundation for statistical computing), using TA, $\mathrm{pH}$, temperature, and salinity. In Experiment 2, salinity and $\mathrm{pH}$ again were measured daily, using a refractometer and certified thermometer (as above), respectively. TA was calculated every $2-4 \mathrm{~d}$ by potentiometric titration, and carbonate chemistry parameters and $P_{\mathrm{CO} 2}$ were calculated daily using the same methods as Experiment 1.

\section{Response variables}

Net calcification was measured using change in buoyant weight for each coral between the start and end of the incubation. Change in buoyant weight was converted to dry weight using the density of aragonite (2.93 $\mathrm{g} \mathrm{cm}^{-3}$ [Davies, 1989]) and seawater density, and values were standardized to area of the coral tissue $\left(\mathrm{cm}^{2}\right)$ and time (d) in units of $\mathrm{mg} \mathrm{CaCO}_{3} \mathrm{~cm}^{-2} \mathrm{~d}^{-1}$. As lesions were deeper and larger in Experiment 2 versus Experiment 1, lesion area in Experiment 2 was subtracted from the colony area to obtain the tissue area used for normalizing calcification. In Experiment 2, net calcification (mg) also was standardized to biomass (mg) and time (d) in units of $\mathrm{d}^{-1}$. Tissue area was determined at the conclusion of the experiment using aluminum foil (Marsh, 1970), and in Experiment 2, biomass was determined by fixing corals in 5\% formalin in seawater for $72 \mathrm{~h}$, decalcifying in $5 \% \mathrm{HCl}$ in seawater, and drying the tissue tunic to a constant 
weight at $60^{\circ} \mathrm{C}$. Prior to drying, endolithic taxa were removed with forceps, and the tissue was rinsed in deionized water. Biomass was standardized to area of the coral tissue $\left(\mathrm{cm}^{2}\right)$ to obtain units of $\mathrm{mg} \mathrm{cm}^{-2}$, and we assumed the tissue area-biomass relationship was consistent among treatment groups.

Regeneration of tissue within the lesions was evaluated photographically as the rate at which new coral tissue filled in the damage (see Fig. 1 in Cameron and Edmunds, 2014). In Experiment 1, pictures of the lesions were recorded with a camera (Olympus $850 \mathrm{SW}, 8$ megapixels) prior to, and following, the incubation. These pictures revealed damaged tissue on the floor of the lesion (scars did not penetrate the full width of the coral tissue layer), and the final photographs were used to evaluate healing based on a two-category assessment of tissue color. Lesions were categorized as "partially healed" when their margins were visible, the lesion area and shape largely were unchanged relative to the first day of the incubation, and the return of normal tissue color was mostly restricted to individual polyps (i.e., not the coenosarc). Lesions were categorized as "mostly healed" when their margins were not clearly visible, and normal tissue color had returned to individual polyps and the coenosarc. There were no corals that could be categorized as fully healed based on the lesion being indistinguishable from the rest of the colony surface.

In Experiment 2, pictures of damaged corals were recorded (Nikon D70 camera, 6 megapixels) prior to incubation, and every $4 \mathrm{~d}$ thereafter until the experiment finished. Pictures were recorded from a fixed distance above the coral, and included a scale bar, and revealed exposed skeleton within the lesion at the start of the experiment. The area of the lesions $\left(\mathrm{cm}^{2}\right)$ was 
calculated at each sampling using ImageJ software (Abramoff et al., 2004), and was used to calculate the rate of healing.

\section{Statistical analysis}

In both experiments, conditions in the tanks (temperature, $\mathrm{pH}, P_{\mathrm{CO} 2}$, TA, and irradiance) were analyzed using two-way, partly nested ANOVAs, with treatment $\left(P_{\mathrm{CO} 2}\right)$ a fixed factor, and tank a random factor nested within treatment. In Experiment 1, area-normalized net calcification was analyzed with a three-way, partly nested ANOVA with $P_{\mathrm{CO} 2}$ and damage (scarred versus undamaged) as fixed factors, and tank a random factor nested within $P_{\mathrm{CO} 2}$. The frequency of corals categorized as partially healed versus mostly healed as a function of treatment (i.e., $\left.P_{\mathrm{CO} 2}\right)$ was analyzed using a $2 \times 2$ contingency table with $\chi^{2}$-test. In Experiment 2 , area- and biomassnormalized net calcification, as well as biomass, were analyzed with three-way, partly nested ANOVAs with $P_{\mathrm{CO} 2}$ and damage (scarred versus undamaged) as fixed factors, and tank as a random factor nested within $P_{\mathrm{CO} 2}$. Lesion areas were expressed as a percentage of initial area, and repeated-measures ANOVA was used to test the effects of time, $P_{\mathrm{CO} 2}$, and their interaction on the change in relative lesion area.

All statistics were carried out with Systat software (Version 11, Systat Software, Inc., San Jose, CA, USA) operating in a Windows environment. The normality and homoscedasticity assumptions of ANOVA were tested through graphical inspection of residuals. 


\section{Results}

\section{Experiment 1: Response to superficial damage}

Treatment conditions. Tanks were maintained close to the targeted conditions (Table 1).

Salinity was consistent across tanks and averaged $35.2(\mathrm{SE}<0.1, \mathrm{n}=6)$. Irradiance did not vary among tanks $\left(F_{4,12}=0.191, P=0.938\right)$ or treatments $\left(F_{1,4}=0.002, P=0.968\right)$, and had a grand mean of $373 \pm 2 \mathrm{mmol}$ photons $\mathrm{m}^{-2} \mathrm{~s}^{-1}( \pm \mathrm{SE}, \mathrm{n}=6)$. Temperature varied among tanks $\left(F_{4,240}=\right.$ 3.262, $P=0.013)$ but not treatments $\left(F_{1,4}=0.056, P=0.825\right)$, yet differences among means were $\leq 0.3^{\circ} \mathrm{C}$; the grand mean was $28.3 \pm 0.1^{\circ} \mathrm{C}( \pm \mathrm{SE}, \mathrm{n}=6)$. TA varied among tanks $\left(F_{4,108}=\right.$ 2.946, $P=0.024)$ but not treatments $\left(F_{1,4}=0.019, P=0.898\right)$, and differences between means were $\leq 10 \mu \mathrm{mol} \mathrm{kg}{ }^{-1}$. Both $P_{\mathrm{CO} 2}$ and $\mathrm{pH}$ varied among treatments $\left(F_{1,4}=6001, P<0.001\right.$ and $F_{1,4}$ $=10819, P<0.001$, respectively $)$, but not tanks $\left(F_{4,317}=0.195, P=0.941\right.$, and $F_{4,498}=0.301, P$ $=0.877$, respectively); these treatments contrasted $420 \pm 3 \mu$ atm versus $1,050 \pm 57 \mu$ atm $P_{\mathrm{CO} 2}$, and a $\mathrm{pH}$ of $8.02 \pm<0.01$ versus $7.69 \pm 0.02($ all mean $\pm \mathrm{SD}, \mathrm{n}=2)$.

Response variables. Mean calcification ranged from $1.07 \pm 0.13 \mathrm{mg} \mathrm{cm}^{-2} \mathrm{~d}^{-1}$ (damaged corals, elevated $P_{\mathrm{CO} 2}$ ) to $1.67 \pm 0.14 \mathrm{mg} \mathrm{cm}^{-2} \mathrm{~d}^{-1}$ (undamaged corals, ambient $P_{\mathrm{CO} 2}$, both $\pm \mathrm{SE}$ ) (Fig. 1A). Mean calcification was depressed $26 \%$ (pooled across $P_{\mathrm{CO} 2}$ treatments) by damage $\left(F_{1,4}=21.205\right.$, $P=0.010)$, but not by $P_{\mathrm{CO} 2}\left(F_{1,4}=2.247, P=0.208\right)$, the interaction between the two $\left(F_{1,4}=\right.$ 3.093, $P=0.153)$, or tank $\left(F_{4,64}=0.598, P=0.666\right)$. For damaged corals, elevated $P_{\mathrm{CO} 2}$ reduced mean calcification $24 \%$, while the effect of $P_{\mathrm{CO} 2}$ on undamaged corals was negligible (mean difference $<0.01 \%$ ). At the end of the experiment, the categorization of the 36 damaged corals 
based on the extent of lesion healing (partially versus mostly healed) was independent of $P_{\mathrm{CO} 2}\left(\chi^{2}\right.$ $=1.003, P=0.317)$.

\section{Experiment 2: Response to deeper scaring}

Treatment conditions. Tanks were maintained close to the targeted treatment conditions (Table 1). Salinity averaged 33.8 across tanks $(\mathrm{SE}<0.1, \mathrm{n}=4)$. Irradiance and temperature did not vary among tanks $\left(F_{2,80}=0.388, P=0.680\right.$, and $F_{2,156}=2.732, P=0.068$, respectively $)$ or treatments $\left(F_{1,2}=8.173, P=0.104\right.$, and $F_{1,2}=0.212, P=0.690$, respectively $)$ and had grand mean values of $627 \pm 9 \mu \mathrm{mol}$ photons $\mathrm{m}^{-2} \mathrm{~s}^{-1}$ and $28.8 \pm 0.1^{\circ} \mathrm{C}$, respectively $( \pm \mathrm{SE}, \mathrm{n}=4) . \quad P_{\mathrm{CO} 2}$ varied among tanks $\left(F_{2,84}=3.370, P=0.039\right)$ and treatments $\left(F_{1,2}=228, P=0.004\right)$, however, differences between tanks were $\leq 81 \mu$ atm. $\mathrm{pH}$ varied among treatments $\left(F_{1,2}=378, P=0.003\right)$ but not tanks $\left(F_{2,80}=2.214, P=0.116\right)$, and TA was consistent among tanks $\left(F_{2,24}=0.879, P=\right.$ $0.428)$ and treatments $\left(F_{1,2}=1.223, P=0.384\right)$. These treatments contrasted $388 \pm 6 \mu$ atm versus $970 \pm 7 \mu$ atm $P_{\mathrm{CO} 2}$, and a $\mathrm{pH}$ of $8.06 \pm<0.01$ versus $7.74 \pm<0.01$ (all mean $\pm \mathrm{SE}, \mathrm{n}=3$ ).

Response variables. Area-normalized calcification ranged from $0.60 \pm 0.05 \mathrm{mg} \mathrm{cm}^{-2} \mathrm{~d}^{-1}$ (damaged corals, elevated $P_{\mathrm{CO} 2}$ ) to $0.79 \pm 0.08 \mathrm{mg} \mathrm{cm}^{-2} \mathrm{~d}^{-1}$ (damaged corals, ambient $P_{\mathrm{CO} 2}$, both mean $\pm \mathrm{SE})$, and was not affected by $P_{\mathrm{CO} 2}\left(F_{1,2}=3.943, P=0.185\right)$, damage $\left(F_{1,2}=2.804, P=\right.$ $0.236)$, the interaction between the two $\left(F_{1,2}=4.030, P=0.182\right)$, or tank $\left(F_{2,72}=0.836, P=\right.$ 0.438) (Fig. 1B). Mean biomass-normalized calcification ranged from $0.071 \pm 0.008 \mathrm{~d}^{-1}$ (damaged corals, elevated $\mathrm{pCO}_{2}$ ) to $0.088 \pm 0.008 \mathrm{~d}^{-1}$ (undamaged corals, ambient $P_{\mathrm{CO} 2}$, both \pm SE) (Fig. 1D), and was reduced by elevated $P_{\mathrm{CO} 2}\left(F_{1,2}=20.577, P=0.045\right)$, with a $10 \%$ decrease across both damage treatments, and was unaffected by damage $\left(F_{1,2}=8.583, P=0.099\right)$, the $P_{\mathrm{CO} 2}$ 
$\times$ damage interaction $\left(F_{1,2}=4.716, P=0.162\right)$, and tank $\left(F_{2,72}=0.047, P=0.954\right)$. Mean biomass ranged from $8.80 \pm 0.70 \mathrm{mg} \mathrm{cm}^{-2}$ (undamaged corals, elevated $P_{\mathrm{CO} 2}$ ) to $9.57 \pm 0.49 \mathrm{mg}$ $\mathrm{cm}^{-2}$ (damaged corals, elevated $P_{\mathrm{CO} 2}$ ) and was not affected by $P_{\mathrm{CO} 2}\left(F_{1,2}=0.511, P=0.549\right.$ ), damage $\left(F_{1,2}=0.184, P=0.710\right)$, the interaction between the two $\left(F_{1,2}=0.004, P=0.954\right)$, or $\operatorname{tank}\left(F_{2,72}=1.749, P=0.181\right)($ Fig. $1 C)$.

At the end of the incubation, lesions were reduced to $20.6 \pm 4.1 \%$ of their original size at ambient $P_{\mathrm{CO} 2}$, and to $22.7 \pm 4.0 \%$ of their original size at elevated $P_{\mathrm{CO} 2}$ (both mean $\pm \mathrm{SE}, \mathrm{n}=20$ ) (Fig. 2). The highest rates of decline in lesion area occurred within the first $3 \mathrm{~d}$ following damage, averaging $9.0 \pm 0.9 \% \mathrm{~d}^{-1}$ in elevated $P_{\mathrm{CO} 2}$, and $7.6 \pm 0.8 \% \mathrm{~d}^{-1}$ in ambient $P_{\mathrm{CO} 2}($ both \pm SE, $\mathrm{n}=20)$. The reduction in size of lesions differed over time $\left(F_{4,8}=9.874, P=0.003\right)$, but was unaffected by $P_{\mathrm{CO} 2}\left(F_{1,2}=0.014, P=0.917\right)$, the $P_{\mathrm{CO} 2} \times$ time interaction $\left(F_{4,8}=1.102, P=0.418\right)$, or tank $\left(F_{2,180}=0.994, P=0.372\right)$.

\section{Discussion}

This study tested the hypothesis that ocean acidification affects the response of massive Porites spp. to damage of differing severities representing the effects of corallivory by fishes in the scraping and gouging functional groups (Bellwood and Choat, 1990). There is a long history of investigating the effects of damage on corals (Cole et al., 2008; Rotjan and Lewis, 2008; Bruckner and Bruckner, 2016), and recent interest in the response of corals to ocean acidification (Chan and Connelly, 2012; Kroeker et al., 2013), but little is known of the interaction between these stressors in terms of their effects on coral performance (but see Renegar et al., 2008; 
Horwitz and Fine, 2014; Hall et al., 2015). A prior, it was reasonable to hypothesize that regeneration of coral tissue and skeleton following damage would be affected by ocean acidification, potentially because the physical and chemical consequences of this phenomenon can alter the use of metabolic energy by metazaoans (Pan et al. 2015), and in reef corals, can modulate holobiont respiration and photochemical efficiency (Anthony et al., 2008; Crawley et al., 2009; Edmunds, 2012; Kaniewska et al., 2012; but see Schneider and Erez, 2006; Comeau et al., 2016), calcification (Erez et al., 2011; Chan and Connelly, 2012), and protein metabolism (Kaniewska et al., 2012; Edmunds and Wall, 2014). In contrast to this expectation, ocean acidification had no effect on the response to damage, as evaluated by area-normalized calcification, biomass, and rate of closure of the lesion (i.e., tissue regeneration) during short experiments in mesocosms.

The effect of damage on calcification of massive Porites spp. varied between experiments, and area-normalized rates were unaffected by $\sim 1,000 P_{\mathrm{CO} 2}$, and remained similar to those previously reported for this genus in Moorea (Comeau et al., 2014b), as well as more broadly for other corals (Pratchett et al., 2015). In Experiment 1, damage affecting 4\% of the surface of the corals reduced area-normalized calcification $\sim 26 \%$ in ambient and elevated $P_{\mathrm{CO} 2}$, while in Experiment 2, more severe damage affecting $\sim 10 \%$ of the surface area of the corals (and removing a deeper layer of skeleton and tissue) did not affect area-normalized or biomass normalized calcification, although $P_{\mathrm{CO} 2}$ reduced biomass-normalized calcification $\sim 10 \%$ (Fig $1 \mathrm{~A}, \mathrm{~B})$. 
The key to reconciling the contrasting results in the two experiments probably lies in differences in the environmental conditions preceding the experiments, and differences between experiments in the physical conditions employed. For instance, while calcification rates in both experiments were within the range of values previously reported for this genus, mean rates in Experiment 1 were double those in Experiment 2 (pooled among $P_{\mathrm{CO} 2}$ and damage treatments), which could reflect the effects of seawater temperature both in the mesocosms and on the reef prior to the experiment. In the mesocosms, mean seawater temperature was $0.6^{\circ} \mathrm{C}$ warmer in Experiment 2 $\left(28.9^{\circ} \mathrm{C}\right)$ compared to Experiment $1\left(28.3^{\circ} \mathrm{C}\right)$, and the warmer conditions in Experiment 2 might have depressed calcification if $\sim 28.3^{\circ} \mathrm{C}$ is close to the thermal threshold for calcification in massive Porites spp. (Pratchett et al., 2015). In situ, seawater temperature from April 2012 to March 2013 (1 y prior to Experiment 1 ) was slightly warmer (mean $=27.7^{\circ} \mathrm{C}, \mathrm{n}=365 \mathrm{~d}$ ) with a warmer winter minimum $\left(26.1^{\circ} \mathrm{C}\right)$ than from April 2013 to March 2014 ( 1 y prior to Experiment 2 ), that was cooler $\left(\right.$ mean $=27.5^{\circ} \mathrm{C}, \mathrm{n}=345 \mathrm{~d}$ ) with a colder winter minimum $\left(25.3^{\circ} \mathrm{C}\right)$ (Washburn 2015). These effects might have established differences in the quality of coral tissue (Fitt et al., 2000; Thornhill et al., 2011) that were associated with reduced calcification in Experiment 2. Light intensity also was higher in Experiment 2 (627 $\mu \mathrm{mol}$ photons $\left.\mathrm{m}^{-2} \mathrm{~s}^{-1}\right)$ than Experiment $1\left(372 \mu \mathrm{mol}\right.$ photons $\left.\mathrm{m}^{-2} \mathrm{~s}^{-1}\right)$ due to logistical constraints, and while this difference is unlikely to have directly depressed calcification in Experiment 2 given the hyperbolic tangent function that relates calcification to light intensity in reef corals (Chalker, 1981), it probably would have accelerated photosynthesis (Hennige et al., 2008). With greater rates of photosynthesis, it is likely that larger quantities of photosynthetically fixed carbon would be translocated to the animal host (Muscatine et al., 1984; Edmunds and Davies, 1986). This enhanced supply of carbon (and the energy it represents) may have eclipsed the metabolic costs 
of repair (Henry and Hart, 2005), thereby allowing the calcification rates of damaged corals to remain similar to those of undamaged corals.

In Experiment 2, stable area-normalized calcification and depressed biomass-normalized calcification at high $P_{\mathrm{CO} 2}$ also requires explanation, and conceivably could be a result of a $P_{\mathrm{CO}^{-}}$ induced increase in biomass. This would depress biomass-normalized calcification, but with more tissue calcifying less rapidly, area-normalized calcification could be sustained (as was observed). Massive Porites spp. uses this strategy to ameliorate its sensitivity to high $P_{\mathrm{CO} 2}$ (Edmunds, 2011), but in the study in which this has been demonstrated, biomass was enhanced at high $P_{\mathrm{CO} 2}$ in association with ad libitum feeding on Artemia spp. (Edmunds, 2011). In the present study in which corals were not fed plankton and experiments lasted $\sim 3$ weeks (cf. 1 month in Edmunds, 2011), $P_{\mathrm{CO} 2}$ was not associated with a change in biomass (Fig. 1C), yet tissue calcifying $10 \%$ less quickly at high $P_{\mathrm{CO} 2}$ supported equal area-normalized calcification at elevated and ambient $P_{\mathrm{CO} 2}$. It is not possible to explain this outcome with the present results, but it could reflect a limitation of the assumption that calcification did not occur within lesions that removed the full tissue thickness (described in methods), and therefore, that the area of the scar should be subtracted from colony area before normalizing calcification to area. If the scaring left sufficient tissue deep within the skeleton to support limited calcification within the scar, and this tissue recovered quickly (as observed), then our area-normalized calcification rates would be upwardly biased by the extent to which the scar area functioned like undamaged areas of the coral in terms of calcification. If this is correct, then potentially the high $P_{\mathrm{CO} 2}$ regime applied in Experiment 2 could have caused a slight overall reduction in area-normalized calcification. 
Previous studies have demonstrated that the effect of damage on the growth of corals varies among species, increasing growth in some (Loya, 1976), while decreasing growth in others (Cox, 1986; Meesters et al., 1994). Loya (1976), for example, found that damaged colonies of the branching coral Stylophora pistillata in the Gulf of Eilat, grew twice as fast as undamaged colonies, and in Moorea, Edmunds and Lenihan (2009) found that the effects of damage ( 67 $\mathrm{mm}^{2}$ gouges) on the calcification of massive Porites spp. depended on environmental conditions; damage accelerated calcification $25 \%$ at $26.7^{\circ} \mathrm{C}$, but depressed calcification $25 \%$ at $29.6^{\circ} \mathrm{C}$. Decreased calcification in damaged corals, as in Experiment 1, is consistent with a trade-off model involving limited resources, for example energy and nitrogen, which are diverted from calcification to tissue regeneration to accelerate recovery (Henry and Hart, 2005). In Experiment 2, calcification and biomass were not affected by damage, which suggests that the energy used for tissue regeneration was not being diverted from calcification or tissue reserves. It is possible that in Experiment 2, carbon resources either were in excess of needs (described above), or were reallocated to repair from other processes, such as reproduction, which can be depressed in damaged corals (Rinkevich 1996).

In the present study, a $P_{\mathrm{CO} 2}$ of $\sim 1,000 \mu$ atm did not affect repair in massive Porites spp. over 19$20 \mathrm{~d}$, after which damage appeared almost fully healed. Healing was evaluated every $4 \mathrm{~d}$ in Experiment 2, and initially was rapid, but slowed over time as predicted from an exponential decay function that describes healing in corals (Meesters et al., 1994; Denis et al., 2011). Rates of healing during Experiment 2 were $4.0 \% \mathrm{~d}^{-1}$ in ambient $P_{\mathrm{CO} 2}$ and $3.9 \% \mathrm{~d}^{-1}$ in elevated $P_{\mathrm{CO} 2}$, which are similar to rates previously reported for massive Porites spp. For example, Cameron and Edmunds (2014) found that small colonies with single sites of excavation damage (each 
$105 \mathrm{~mm}^{2}$ and $2-5 \mathrm{~mm}$ deep) healed at $\sim 2.5 \% \mathrm{~d}^{-1}$ over $21 \mathrm{~d}$, while Edmunds and Lenihan (2009) reported tissue healing of $4-5 \% \mathrm{~d}^{-1}$ over $10 \mathrm{~d}$ for small colonies with lesions $\sim 67 \mathrm{~mm}^{2}$ and $1-2$ mm deep.

The conclusion of this study that healing in massive Porites spp. is unaffected by high $P_{\mathrm{CO} 2}$, has several caveats relating to the extent of damage, the duration of the experiment, the magnitude of the $P_{\mathrm{CO} 2}$ regime applied, and the potential for calcification to occur in severe (i.e., deep) scars such as those created in Experiment 2. First, the present results can only be applied to larger corals (i.e., > $4 \mathrm{~cm}$ diameter), cases of more severe damage (e.g., multiple bites on each colony), and longer durations of exposure to high $P_{\mathrm{CO} 2}$, with caution, because all three cases require extrapolation beyond the scope of this study. Second, while the treatments were designed to be ecologically relevant, with the $P_{\mathrm{CO} 2}$ regime simulating a pessimistic projection for the next $\sim 200$ y, more extreme $P_{\mathrm{CO} 2}$ regimes could produce different results. For instance, wound healing in massive Porites spp. was slowed in two of three studies in which $P_{\mathrm{CO} 2}$ regimes extended from 1,381-4,000 $\mu$ atm (reductions in Horwitz and Fine [2014] and Renegar et al. [2008], but not in Hall et al. [2015]). Therefore, in microhabitats where seawater $P_{\mathrm{CO} 2}$ already exceeds $1,000 \mu$ atm (e.g., natural $\mathrm{CO}_{2}$ seeps [Fabricius et al., 2011]), or further than $\sim 100 \mathrm{y}$ into the future under pessimistic predictions of human $\mathrm{CO}_{2}$ emissions (van Vuuren et al., 2011), it remains possible that coral tissue regeneration will be impaired in massive Porites spp. Finally, our results draw attention to the need to know more about the capacity for Porites spp. to calcify in wounded areas where only a small fraction of the original host tissue remains, and the speed with which normal rates of calcification resume in such areas as tissue healing progresses. 
Overall, the responses to ocean acidification described herein supports evidence of the physiological robustness of massive Porites spp. to $P_{\mathrm{CO} 2}$ as high as $\sim 2,000 \mu$ atm (Fabricius et al., 2011; Comeau et al., 2014b), by revealing that members of this taxon can recover equally well from modest damage at both ambient and elevated $P_{\mathrm{CO} 2}(\sim 1,000 \mu \mathrm{atm})$. As three other coral species and massive Porites spp. show depressed tissue regeneration at 1,800 $\mu$ atm (versus ambient) (Horwitz and Fine, 2014), as does P. porites (but not P. astreoides) at pH 7.6 (ca. 2,105 $\mu$ atm $P_{\mathrm{CO} 2}$, see Hall et al., 2012) (Hall et al., 2015), and $P$. astreoides at 1,381 $\mu$ atm $P_{\mathrm{CO} 2}$ (Renegar et al., 2008), the resilience of wound healing in massive Porites spp. may have a threshold around 1,000 $\mu$ atm $P_{\mathrm{CO} 2}$, beyond which impairment occurs. Together, the present results suggest that damaged massive Porites spp. will be able to maintain tissue regeneration and perhaps calcification at $P_{\mathrm{CO} 2}$ values expected by the end of the current century.

\section{Acknowledgements}

This research was supported by grants from the U.S. National Science Foundation (OCE 0417412, 10-26851, 12-36905, and 14-15268), and gifts from the Gordon and Betty Moore Foundation. We are grateful to N. Evensen, and V. Moriarty for assistance in the field. This is contribution number xxx of the marine biology program of California State University, Northridge, and the work represents a portion of the MS thesis research completed by A. Yarid.

\section{References}

Abràmofff, M.D., Magalhães, P.J., Ram, S.J., 2005. Image processing with ImageJ Part II. Biophotonics Int. 11, 36-43. 
Anthony, K.R.N., Kline, D.I., Diaz-Pulido, G., Dove, S., Hoegh-Guldberg, O., 2008. Ocean acidification causes bleaching and productivity loss in coral reef builders. Proc. Natl. Acad. Sci. U.S.A. 105, 17442-17446.

Bellwood, D.R., Choat, J.H., 1990. A functional analysis of grazing in parrotfishes (family Scaridae): the ecological implications. Environ. Biol. Fishes 28, 189-214.

Bindoff, N.L., Willebrand, J., Artale, V., Cazenave, A., Gregory, J., Gulev, S., Hanawa, K., Le Quéré, C., Levitus, S., Nojiri, Y., Shum, C.K., Talley L.D., Unnikrishnan, A., 2007. Observations: Oceanic Climate Change and Sea Level, in: Solomon, S., Qin, D., Manning, M., Chen, Z., Marquis, M., Averyt, K.B., Tignor, M., Miller, H.L. (Eds.), Climate Change 2007: The Physical Science Basis. Contribution of Working Group I to the Fourth Assessment Report of the Intergovernmental Panel on Climate Change. Cambridge University Press, Cambridge, and New York.

Bosserelle, P., Berteaux-Lecellier, V., Chancerelle, Y., Hédouin, L., Nugues, M., Wallace, C., Pichon, M., 2014. Guide d'identification des coraux de Moorea. CRIOBE, Perpignan Moorea.

Bruckner, A.W., Bruckner, R.J. 2016. Mechanical lesions and corallivory. In: Woodley, C.M., Downes, C.A., Bruckner, A.W., Porter, J.W., Galloway, S.B. (Eds.), Diseases of coral. John Wiley \& Sons, Hoboken, pp 242-265.

Cameron, C.M., Edmunds, P.J., 2014. Effects of simulated fish predation on small colonies of massive Porites spp. and Pocillopora meandrina. Mar. Ecol. Prog. Ser. 508, 139-148.

Chalker, B.E., 1981. Simulating light-saturation curves for photosynthesis and calcification by reef-building corals. Mar. Biol. 63, 135-141. 
Chan, N.C.S., Connolly, S.R., 2013. Sensitivity of coral calcification to ocean acidification: A meta-analysis. Glob. Chang. Biol. 19, 282-290.

Cole, A.J., Pratchett, M.S., Jones, G.P., 2008. Diversity and functional importance of coralfeeding fishes on tropical coral reefs. J. Compil. 286-307.

Comeau, S., Edmunds, P.J., Lantz, C.A., Carpenter, R.C., 2014a. Water flow modulates the response of coral reef communities to ocean acidification. Scientific Reports. 4, 6681.

Comeau, S., Edmunds, P.J., Spindel, N.B., Carpenter, R.C., 2014b. Fast coral reef calcifiers are more sensitive to ocean acidification in short-term laboratory incubations. Limnol. Oceanogr. 59, 1081-1091.

Comeau, S., Carpenter, R.C., Edmunds, P.J., 2016. Effects of $\mathrm{pCO}_{2}$ on photosynthesis and respiration of tropical scleractinian corals and calcified algae. ICES J. Mar. Sci. fsv267.

Cox, E.F., 1986. The effects of a selective corallivore on growth-rates and competition for space between two species of Hawaiian corals. J. Exp. Mar. Biol. Ecol. 101, 161-174.

Crawley, A., Kline, D.I., Dunn, S., Anthony, K., Dove, S., 2010. The effect of ocean acidification on symbiont photorespiration and productivity in Acropora formosa. Glob. Chang. Biol. 16, 851-863.

Denis, V., Debreuil, J., De Palmas, S., Richard, J., Guillaume, M.M.M., Bruggemann, J.H., 2011. Lesion regeneration capacities in populations of the massive coral Porites lutea at Réunion Island: Environmental correlates. Mar. Ecol. Prog. Ser. 428, 105-117.

Dickson, A.G., Sabine, C.L., Christian, J.R., 2007. Guide to best practices for CO2 measurements. PICES Special Publication, 3.

Doney, S.C., Fabry, V.J., Feely, R.A., Kleypas, J.A., 2009. Ocean acidification: the other $\mathrm{CO}_{2}$ problem. Annu. Rev. Mar. Sci. 1, 169-192. 
Edmunds, P.J., 2009. Effect of acclimatization to low temperature and reduced light on the response of reef corals to elevated temperature. Mar. Biol. 156, 1797-1808.

Edmunds, P.J. 2011. Zooplanktivory ameliorates the effects of ocean acidification on the reef coral Porites spp. Limnol. Oceanogr. 56, 2402-2410

Edmunds, P.J., Davies, P.S., 1986. An energy budget for Porites porites (Scleractinia). Mar. Biol. 92, 339-347.

Edmunds, P.J., Lenihan, H.S., 2010. Effect of sub-lethal damage to juvenile colonies of massive Porites spp. under contrasting regimes of temperature and water flow. Mar. Biol. 157, 887-897.

Edmunds, P.J., Wall, C.B. 2014. Evidence that high pCO2 affects protein metabolism in tropical reef corals. Biol. Bull 227, 68-77.

Edmunds, P.J., 2012. Effect of $\mathrm{pCO}_{2}$ on the growth, respiration, and photophysiology of massive Porites spp. in Moorea, French Polynesia. Mar. Biol. 159, 2149-2160.

Erez, J., Reynaud, S., Silverman, J., Schneider, K., Allemand, D., 2011. Coral calcification under ocean acidification and global change. In: Dubinsky, Z., Stambler, N. (Eds.), Coral Reefs: An ecosystem in transition. Springer, Dordrecht, pp. 151-176.

Fabricuis, K., Langdon, C., Uthicke, S., Humphrey, C., Noonan, S., et al. 2011. Loser and winners in coral reefs acclimatized to elevated carbon dioxide concentrations. Nat. Clim. Change. 1, 165-169.

Fitt, W.K., McFarland, F.K., Warner, M.E., Chilcoat, G.C., 2000. Seasonal patterns of tissue biomass and densities of symbiotic dinoflagellates in reef corals and relation to coral bleaching. Limnol. Oceanogr. 45, 677-685. 
Forsman, Z.H., Barshis, D.J., Hunter, C.L., Toonen, R.J., 2009. Shape-shifting corals: molecular markers show morphology is evolutionarily plastic in Porites. BMC Evol. Biol. 9, 45.

Frydl, P., 1979. The effect of parrotfish (Scaridae) on coral in Barbados, W.I. Int. Rev. der gesamten Hydrobiol. und Hydrogr. 64, 737-748.

Hall, E.R., Vaughn. D., Crosby M.P., 2012. Development of ocean acidification flow-thru experimental raceway units (OAFTERU). Proc. $12^{\text {th }}$ Int. Coral Reef Symp. 8D_2

Hall, E.R., DeGroot, B.C., Fine, M., 2015. Lesion recovery of two scleractinian corals under low pH conditions: Implications for restoration efforts. Mar. Pollut. Bull. 100, 321-6.

Hennige, S.J., Smith, D.J., Perkins, R., Consalvey, M., Paterson, D.M., Suggett, D.J., 2008. Photoacclimation, growth and distribution of massive coral species in clear and turbid waters. Mar. Ecol. Prog. Ser. 369, 77-88.

Henry, L.A., Hart, M., 2005. Regeneration from injury and resource allocation in sponges and corals - A review. Int. Rev. Hydrobiol. 90, 125-158.

Hixon, M.A., 1997. The effects of reef fishes on corals and algae, in: Birkeland C. (Eds.), Life and death of coral reefs. Chapman and Hall, New York, pp. 230-248.

Horwitz, R., Fine, M., 2014. High $\mathrm{CO}_{2}$ detrimentally affects tissue regeneration of Red Sea corals. Coral Reefs 33, 819-829.

Hughes, R.N., 1983. Evolutionary ecology of colonial reef-organisms, with particular reference to corals. Biol. J. Linn. Soc. 20, 39-58.

Hughes, T.P., Jackson, J.B.C., 1985. Population dynamics and life histories of foliaceous corals. Ecol. Monogr. 55, 141-166.

Hurlbert, S.H. 1984. Pseudoreplication and the design of ecological field experments. Ecol. Monogr. 54, 187-211. 
Jackson, J.B.C., 1979. Morphological strategies of sessile animals, in: Larwood, G., Rosen, B.R., (Eds.), Biology and systematics of colonial organisms. Academic Press, London and New York, pp. 499-553.

Jackson, J.B.C., Coates, A.G., 1986. Life cycles and evolution of clonal (modular) animals. Phil. Trans. R. Soc. Lond. 313, 7-22.

Kaniewska, P., Campbell, P.R., Kline, D.I., Rodriguez-Lanetty, M., Miller, D.J., Dove, S., Hoegh-Guldberg, O., 2012. Major cellular and physiological impacts of ocean acidification on a reef building coral. PLoS One 7, e34659.

Kroeker, K.J., Kordas, R.L., Crim, R., Hendriks, I.E., Ramajo, L., Singh, G.S., Duarte, C.M., Gattuso, J.P., 2013. Impacts of ocean acidification on marine organisms: Quantifying sensitivities and interaction with warming. Glob. Chang. Biol. 19, 1884-1896.

Lavigne, H., Gattuso, J.P., 2012. Seacarb, seawater carbonate chemistry with R. R package version 2.4.10. http:// CRAN.R-project.org/package seacarb, 2013.

Leniha, H.S., Edmunds, P.J. 2010. Response of Pocillopora verrucosa to corallivory varies with environmental conditions. Mar. Ecol. Prog. Ser. 409, 51-63

Loya, Y., 1976. Skeletal regeneration in a Red Sea scleractinian coral population. Nature 261, $490-491$.

Marsh, J.A., 1970. Primary productivity of reef-building calcareous red algae. Ecology. 51, 255263.

Meesters, E.H., Noordeloos, M., Bak, R.P.M., 1994. Damage and regeneration: links to growth in the reef-building coral Montastrea annularis. Mar. Ecol. Prog. Ser. 112, 119-128.

Meesters, E.H., Wesseling, I., Bak, R.P.M., 1996. Partial mortality in three species of reefbuilding corals and the relation with colony morphology. Bull. Mar. Sci. 58, 838-852. 
Meesters, E.H., Pauchli, W., Bak, R.P.M., 1997. Predicting regeneration of physical damage on a reef-building coral by regeneration capacity and lesion shape. Mar. Ecol. Prog. Ser. 146, 91-99.

Muscatine, L., Falkowski, P., Porter, J., Dijbinsky, Z., 1984. Fate of photosynthetically-fixed carbon in light and shade adapted colonies of the symbiotic coral Stylophora pistillata. Proc. Roy. Soc. Lond. 222, 181-202.

Nagelkerken, I., Bak, R., 1998. Differential regeneration of artificial lesions among sympatric morphs of the Caribbean corals Porites astreoides and Stephanocoenia michelinii. Mar. Ecol. Prog. Ser. 171, 279-283.

Nagelkerken, I., Meesters, E.H., Bak, R.P.M., 1999. Depth-related variation in regeneration of artificial lesions in the Caribbean corals Porites astreoides and Stephanocoenia michelinii. J. Exp. Mar. Biol. Ecol. 234, 29-39.

Oren, U., Benayahu, Y., Lubinevsky, H., Loya, Y., 2001. Colony integration during regeneration in the stony coral Favia favus. Ecology 82, 802-813.

Palumbi, S.R., Jackson, J.B.C., 1982. Ecology of cryptic coral reef communities. II. Recovery from small disturbance events by encrusting bryozoa: the influence of "host" species and lesion size. J. Exp. Mar. Biol. Ecol. 64, 103-115.

Pan, T.-C.F., Applebaum, S.L., Manahan, D.T., 2015. Experimental ocean acidification alters the allocation of metabolic energy. Proc. Natl. Acad. Sci. U.S.A. 2015, 2-7.

Pratchett, M.S., Anderson, K.D., Hoogenboom, M.O., Widman, E., Baird, A.H., Pandolfi, J.M., Edmunds, P.J., Lough, J.M., 2015. Spatial, temporal and taxonomic variation in coral growth - implications for the structure and function of coral reef ecosystems. Oceanogr. Mar. Biol. Annu. Rev. 53, 215-296. 
Reese, E.S., 1977. Coevolution of corals and coral feeding fishes of the family Chaetodontidae. Proc. $3^{\text {rd }}$ Int. Coral Reef Symp. 1, 267-274.

Renegar, D.A., Blackwelder, P.L., Moulding, A.L., 2008. Coral ultrastructural response to elevated $\mathrm{pCO}_{2}$ and nutrients during tissue repair and regeneration. Proc. $11^{\text {th }}$ Int. Coral Reef Symp. 2: 1320-1324

Rinkevich, B., 1996. Do reproduction and regeneration in damaged corals compete for energy allocation? Mar. Ecol. Prog. Ser. 143, 297-302.

Rotjan, R.D., Lewis, S.M., 2005. Selective predation by parrotfishes on the reef coral Porites astreoides. Mar. Ecol. Prog. Ser. 305, 193-201.

Rotjan, R.D., Lewis, S.M., 2008. Impact of coral predators on tropical reefs. Mar. Ecol. Prog. Ser. 367, 73-91.

Schneider, K., Erez, J., 2006. The effect of carbonate chemistry on calcification and photosynthesis in the hermatypic coral Acropora eurystoma. Limnol. Oceanogr. 51, $1284-1293$.

Davies, P.S, 1989. Short-term growth measurements of corals using an accurate buoyant weighing technique. Mar. Biol. 101, 389-395.

Thornhill, D.J., Rotjan, R.D., Todd, B.D., Chilcoat, G.C., Iglesias-Prieto, R., Kemp, D.W., LaJeunesse, T.C., Reynolds, J.M., Schmidt, G.W., Shannon, T., Warner, M.E., Fitt, W.K., 2011. A connection between colony biomass and death in Caribbean reef-building corals. PLoS One 6, e29535.

Veron, J.E.N., Pichon, M., 1982. Scleractinia of eastern Australia. Part IV: Family Poritidae. Australian Institute of Marine Science and Australian National University Press. 
van Vuuren, D.P., Edmonds, J., Kainuma, M., Riahi, K., Thomson, A., Hibbard, K., Hurtt, G.C., Kram, T., Krey, V., Lamarque, J.F., Masui, T., Meinshausen, M., Nakicenovic, N., Smith, S.J., Rose, S.K., 2011. The representative concentration pathways: An overview. Climate Change 109, 5-31.

Washburn, L., 2015. MCR LTER: Coral Reef: Ocean Currents and Biogeochemitsry: salinity, temperature and current at CTD and ADCP mooring FOR05 from 2005 ongoing. Knblter-mcr.30.30 


\section{Figures}

Figure 1. Effects of manipulative experiments testing the effects of damage on calcification and biomass of massive Porites spp.: (A) area-normalized calcification for Experiment $1(19 \mathrm{~d}, \mathrm{n}=$ 18 treatment $\left.^{-1}\right),(B)$ area-normalized calcification for Experiment $2\left(20 \mathrm{~d}, \mathrm{n}=20\right.$ treatment $\left.^{-1}\right),(\mathrm{C})$ biomass for Experiment $2\left(\mathrm{n}=20\right.$ treatment $\left.^{-1}\right)$, and (D) biomass-normalized calcification for Experiment $2\left(n=20\right.$ treatment $\left.^{-1}\right)$. Values displayed are means $\pm S E$.

Figure 2. Percent of the original lesion area remaining on damaged corals as a function of time and treatment $\left(P_{\mathrm{CO} 2}\right.$ regime $)$ in Experiment 2. Lesions were $2.56 \pm 0.08 \mathrm{~cm}^{2}$ when first administered. Mean \pm SE shown $\left(n=20\right.$ measurement $\left.^{-1}\right)$ 


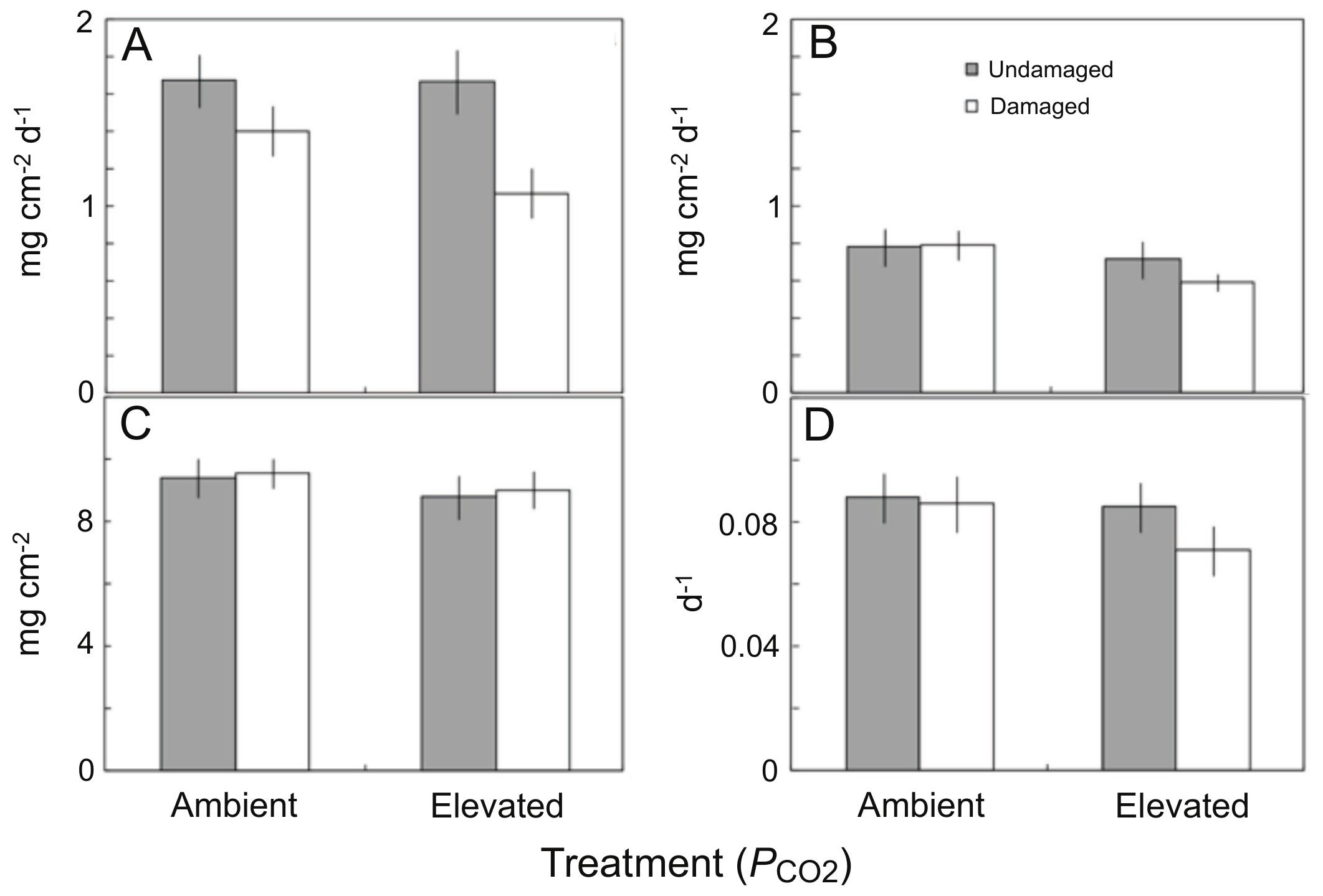




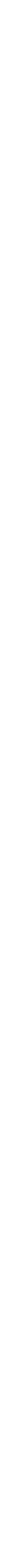

Figure 2

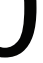


Table 1. Summary of the tank parameters for Experiments 1 (19 d) and Experiment 2 (20 d). Mean \pm SE (n) shown.

\begin{tabular}{|c|c|c|c|c|c|c|c|c|}
\hline Experiment & Treatment & Tank & Temperature $\left({ }^{\circ} \mathrm{C}\right)$ & $\begin{array}{l}\text { Irradiance } \\
\left(\mu \mathrm{mol} \text { photons } \mathrm{m}^{-2} \mathrm{~s}^{-1}\right)\end{array}$ & $\mathrm{pH}$ & $P_{\mathrm{CO} 2}(\mu \mathrm{atm})$ & $\mathrm{TA}\left(\mu \mathrm{mol} \mathrm{kg}{ }^{-1}\right)$ & $\Omega_{\text {arag }}$ \\
\hline \multirow[t]{6}{*}{1} & Ambient & 1 & $28.4 \pm 0.1(41)$ & $362 \pm 5(3)$ & $8.06 \pm 0.01(61)$ & $401 \pm 8(41)$ & $2297 \pm 3(17)$ & $3.74 \pm 0.01$ \\
\hline & & 3 & $28.2 \pm 0.1(41)$ & $377 \pm 12(3)$ & $8.06 \pm 0.01(61)$ & $384 \pm 6(41)$ & $2289 \pm 4(19)$ & $3.80 \pm 0.01$ \\
\hline & & 8 & $28.4 \pm 0.1$ & $373 \pm 13(3)$ & $8.07 \pm 0.01(61)$ & $380 \pm 6(41)$ & $2288 \pm 3(18)$ & $3.85 \pm 0.01$ \\
\hline & Elevated & 4 & $28.4 \pm 0.1(41)$ & $365 \pm 25$ (3) & $7.74 \pm 0.01(61)$ & $976 \pm 38(41)$ & $2289 \pm 3(21)$ & $2.09 \pm 0.01$ \\
\hline & & 7 & $28.3 \pm 0.1(41)$ & $376 \pm 20(3)$ & $7.73 \pm 0.01(61)$ & $978 \pm 31(41)$ & $2298 \pm 2(18)$ & $2.07 \pm 0.01$ \\
\hline & & 9 & $28.1 \pm 0.1(41)$ & $379 \pm 9(3)$ & $7.74 \pm 0.01(61)$ & $956 \pm 33(41)$ & $2288 \pm 3(21)$ & $2.09 \pm 0.01$ \\
\hline \multirow[t]{4}{*}{2} & Ambient & 1 & $28.8 \pm 0.1(41)$ & $636 \pm 14(21)$ & $8.01 \pm 0.01(21)$ & $422 \pm 17(21)$ & $2210 \pm 17(21)$ & $3.36 \pm 0.07$ \\
\hline & & 6 & $28.9 \pm 0.1(40)$ & $647 \pm 19(21)$ & $8.02 \pm 0.01(21)$ & $418 \pm 12(21)$ & $2268 \pm 32(7)$ & $3.58 \pm 0.09(21)$ \\
\hline & Elevated & 2 & $28.8 \pm 0.1(40)$ & $621 \pm 18(21)$ & $7.67 \pm 0.01(21)$ & $1091 \pm 29(23)$ & $2262 \pm 14(7)$ & $1.83 \pm 0.05$ \\
\hline & & 7 & $29.0 \pm 0.1(40)$ & $604 \pm 14(21)$ & $7.70 \pm 0.01(21)$ & $1010 \pm 26(23)$ & $2283 \pm 15(7)$ & $2.00 \pm 0.04(21)$ \\
\hline
\end{tabular}

